\title{
The urgency of harmonization between investment law in Indonesia and international law in capital investment disputes resolution
}

\author{
Abdul Halim Barkatullah ${ }^{1}$, Djumadi ${ }^{2 *}$ \\ ${ }^{1,2}$ Faculty of Law, Universitas Lambung Mangkurat, Banjarmasin, Indonesia
}

\section{Keywords \\ Investment \\ Disputes \\ Capital investment}

Received: 12 April 2018

Accepted: 24 May 2018

Published: 8 June 2018

\begin{abstract}
In the era of trade liberalization marked with mega competition, investors have been more freely to invest. For that the recipient of capital must prepare various means to attract investors. Consideration for potential investors, if he wants to invest his capital abroad is the existence of dispute resolution institutions between investors and the host country. In Indonesia after the Capital Market Law settlement of investment disputes, in the resolution of investment disputes between investors and the Government of the Republic of Indonesia through arbitration institutions. Indonesia has ratified the New York Convention 1958, then the convention becomes national law. This means that the foreign arbitral award will automatically be recognized and enforceable in Indonesia. Arbitration institutions as one of the Alternative Dispute Resolution (ARD) in Indonesia has been legitimately stronger with the enactment of Arbitration and ADR law. With the issuance of this law, doubts on the execution of arbitral awards, especially international arbitral awards can be minimized. Thus, the arrangements of foreign investment in Indonesia should also be harmonize with the regulations of International Law, in this case the International Trade Law of GATT/WTO and International Center for the Settlement of Investment Disputes (ICSID) Convention on the settlement of investment disputes between States and Nationals of other States. This does not mean that Indonesia has transferred its sovereignty to the International Law, since the principles of GATT/WTO has exceptions and the implementation of the ICSID Convention in dispute resolution should have prior written approval from the Government of Indonesia.
\end{abstract}

(C) 2018 The Author(s). Published by TAF Publishing.

\section{INTRODUCTION}

Capital investment or investment is an important pillar in the economic growth of a state (Bryant \& Javalgi, 2016) because the economy of the State that wants to grow sustainably requires continuous capital. With low per capita income, Indonesia fosters capital at high speed to pursue higher-income economies. The need for capital continuously can only be met if the supporting factors that hamper the investment climate can be overcome, such as by improving coordination between central and local government agencies, creating efficient bureaucracy with legal certainty in the field of investment, economic cost of high competitiveness as well as a conducive business climate in the field of employment and business security (Pradhan, Arvin,
Nair, \& Bennett, 2017).

With improvements in these areas, the hope of obtaining capital continuously will be realized. For that in relation to investment, it is necessary and worth highlighting some fundamental changes that leads to mobility increase. Investment policies that contain restrictions and are widespread practice in virtually all developing countries should be replaced by more open investment policies. Nondiscrimination and equal treatment for domestic capital and foreign capital are accepted as one of the important principles in investment policy and also reducing the negative list of investment as one of the policies that can encourage investment. Indonesia's investment policy must be harmonized with major changes through deregulation of a

${ }^{*}$ corresponding author: Djumadi

†email: dr.djumadi.sh@gmail.com 
pragmatic nature. Therefore, the Investment Law should regulate the important things, such as all matters relating to direct investment activities in all sectors covering the basic investment policy, the form of economic development linked with the economic actors embodied by the regulation of the development of investment and investment responsibilities as well as investment facilities, approval and licensing of coordinates and implementation of investment policies in which regulates the institutional affairs of investment and the provisions governing the disputes resolution. Because the investors want a convenience way conducting business, that resulting in competition among developing countries to attract investors, so that each State competes to provide convenience for investment embodied in the form of law or government policy as a form of legal certainty for investors.

Furthermore, investment facilities are provided considering the level of foreign economic power and the financial condition of the State and should be promotive compared to facilities provided by other States. The importance of the certainty of this investment facility requires more detailed arrangements on the forms of fiscal facilities, facilities on land rights, immigration and import licensing facilities. Thus, the Investment Law must be able to accommodate the competition, therefore the Investment Law which has been the legal basis for investment activities in Indonesia needs to be replaced because it is no longer appropriate to the challenge of the need to accelerate the development of the national economy through the construction of national legal development in the field of investment that is competitive and in favor of the national interest.

The enactment of Law Number 25 Year 2007 concerning Capital Investment is expected to accommodate various investment constraints that have occurred for the sake of achieving better economic growth. The philosophical reason of the Investment Law is at least seen from its consideration, letter $\mathrm{c}$ which states: "that in order to accelerate the development of the national economy and to create the political and economic sovereignty of Indonesia, it is deemed necessary to increase capital investment in order to turn economic potential into real economic strength, by way of utilizing domestic and overseas funds";

In the consideration letter $\mathrm{d}$ also states: "that in order to face changes in the global economy and participation by Indonesia in various international relationships it is deemed necessary to create a more conducive and promotable investment climate that also provides legal certainty, justice and efficiency while considering the national economic interests".

\section{THE BENEFIT OF FOREIGN CAPITAL INVESTMENT FOR SUPPORTING DEVELOPMENTTHE BENEFIT OF FOR- EIGN CAPITAL INVESTMENT FOR SUPPORTING DEVEL- OPMENT}

In various literature on economic law or business law, the terminology of investment can be mean direct investments by domestic investors, Foreign Direct Investment (FDI) and Foreign Indirect Investment (FII). For this last term is also known as an investment in the form of portfolio i.e., purchasing stock through capital market.

The presence of foreign investors in a country has considerable large benefits (multiplier effect). The intended benefit is that the presence of foreign investors can absorb labor in the recipient countries; can create demand for domestic products as raw materials; increase foreign exchange if foreign investors are export-oriented, can supplement State income from the tax sector; the transfer of technology and transfer of know how. Seen from this point of view, the presence of investors is quite instrumental in economic development in areas where FDI runs its activities. The importance of the presence of foreign investors is stated by Azeem (2014): "Direct investment is better when compared to portfolio investment, because direct investment is more permanent. In additional, direct investment (1) Provide employment opportunities for the people; (2) Has the power of procurement in the local economy; (3) Provide residues either in the form of equipment or technology transfer; (4) When production is exported to provide a road or marketing path that can be traced by local entrepreneurs in addition to instantly providing additional foreign exchange and taxes to the State; (5) More resistance to fluctuations in interest and foreign currency; (6) Provide political protection and territorial security because if investors come from a powerful country undoubtedly security assistance will also be provided.

Although the presence of investors brings benefits to the recipient country on the other hand investors who want to invest is also cannot be separated from the business oriented whether the capital invested is safe and biased to generate profits. As Mallor, Barnes, Bowers, and Langvardt (2004) said that:

"Before an American firm decides to establish a manufacturing operation abroad. Its officers must examine a wide variety of legal issues. Some of the issues are protection of patents and trademarks. Foreign labor laws may be very different from American law and may impose long term obligations on the employer for example Japanese customs to hire an employee for life and in the Netherlands an em- 
ployer must obtain governmental approval to dismiss an employee." So it is understandable why foreign investors before investing their capital, they conduct preliminary research through feasibility study, whether from legal aspect, financial, and politics if it is conducive to doing business in the country to be addressed. It is important to predict the risks to be faced. The cautious nature of investors is understandable considering the capital that is carried not solely in the form of cash, but in the form of intangible assets, namely Intellectual Property Rights (IPR). As it is known the cost to get IPR is not small. So it is reasonable that foreign investors expected, IPR which is part of the capital invested need to get legal protection in the addressing country. There is also another view that suggests that the presence of FDI in addition to bring a positive impact, can also bring negative impact. This is revealed from the thoughts expressed by Elgamodi (2017):

"It should however, be clearly understood from the beginning that the foreign investor is not motivated by consideration of extending aid for development. The prime motivation is commercial, and expects returns for his investment." Therefore, it is also reasonable that the views expressed by various parties, that the presence of foreign investors cannot be separated from the business world that is looking for profits.

\section{THE FOREIGN CAPITAL INVESTMENT DISPUTE IN IN- DONESIA}

Article 32 of Law No. 25 Year 2007 concerning Capital Investment stated (1) Capital investment disputes between the Government and investors shall first be settled through deliberation towards consensus; (2) If such deliberation towards consensus stipulated in paragraph (1) fails, the settlement of dispute shall be carried out through arbitration or alternative dispute settlement or in court in accordance with prevailing laws and regulations; (3) A capital investment dispute between the Government and a domestic investor shall be settled through arbitration based on agreement between the parties, and if such arbitration fails, the settlement of dispute shall be conducted in court; and (4) A capital investment dispute between the Government and a foreign investor shall be settled through international arbitration based upon agreement between the parties.

One thing that is often become a consideration of potential investors if he wants to invest his capital abroad, is the existence of dispute resolution institutions between investors and host countries. Conventionally in every country in the world is providing dispute resolution institution through litigation, which in theory of constitutional law known as the judiciary. However, if a dispute resolution between investor and host country is settled through litigation there is a doubt among potential foreign investors.

In another words the degree of objectivity of the dispute resolution is in doubt. Theoretically indeed the existence of judicial institutions (judiciary) is independent. This means that this institution cannot be influenced by other institutions (executive and legislative). But psychologically, in the settlement of the dispute between a foreign investor and the host state, the court's credibility in subjective factor or justice would be difficult to avoid since he (the judges) is a citizen of the host state (Ahmad \& Mazlan, 2015; Hiransomboon, 2017; Indonesia Investment, 2017; Raksorn, 2016). Therefore, it is natural that foreign investors want to know in advance whether it is possible to settle disputes outside the court.

Regarding the choice of dispute resolution, it is interesting to be listen to Longdong (1998) has to say:

"A major consideration for investors to invest in that adequate legal guarantees provide a means of dispute resolution through foreign arbitration against losses that may arise as a result of investment. Investors and foreign traders are always trying to escape the judiciary of developing countries because they feel they do not know the laws of their own country. Also, there is a doubt that the local judiciary will be objective. Another reason is whether the state judiciary can examine international trade disputes and such complex technology transfer." The same thing is also expressed by Goodpaster (1995). There are various reasons for choosing an arbitration as a place for dispute resolution namely: "In the world of international trade the visible trend is the liberalization of arbitration rules/law to further encourage the use of arbitration rather than dispute settlement through the litigation process. In general, this law is designed to provide maximum autonomy of freedom and flexibility in resolving disputes. This is done by authorizing the parties to appoint law or fair principles applicable to disputes between them and also authorize them to elect arbitrators as well as procedural rules applicable to arbitration. This means that the parties do not need to apply local law to the dispute they are facing."

\section{Some Examples of Investment Disputes in Indonesia Amco Asia corporation et.al v. the Republic of Indonesia No. $A R B / 81 / 8,17$ Oktober 1990}

This is a dispute between a foreign investor and the Government of Indonesia was adjudicated by ICSID in 1990. This dispute stems from a disagreement between Amco Asia, one of the US company and Wisma Ltd. which previously held 
Lease and Management Agreement in 1968. Amco Asia Corporation established its subsidiary Amco Ltd. under Indonesian law. In its petition contains an ICSID arbitration clause in concerning any dispute which may arise between the Government of RI and Amco Ltd. Furthermore, Amco Ltd. made a "Sub-Lease Agreement" with Aeropacific to finance, build and manage the hotel. After difficulties arose related to the "Sub-Lease Agreement" on the date of October 16th, 1978, Wisma Ltd. and Amco Ltd. made a "Profit - Sharing Agreement" for management of Kartika Plaza hotel. The dispute arose between PT. Amco and PT. Wisma, especially regarding the amount of each party's share under the "Profit Sharing Agreement". On the date of March 31th- April 1st, 1980, the Hotel is occupied by the army and the hotel management is taken over by Wisma Ltd. BKPM revoked the investment permit of Amco Ltd. on the date of July 9th, 1980. The Jakarta High Court based on the lawsuit by Wisma Ltd. to Amco Ltd. in November 1983 annulled "Management and Lease Agreement" 1968 and "Profit Sharing Agreement" 1978.

On the date of January 15th, 1981, Amco submitted an ICSID arbitration request, questioned the jurisdiction of the Government of the Republic of Indonesia to freeze its investment and permits, and demanded compensation of US $\$ 12,393,000$ including interest and fees. The Arbitration Council decided that, first of all, that the parties did not declare an agreement on the rules used to resolve the dispute arising between them. The Arbitration Council applies Indonesian law, that is, the law applicable to contracts made by the parties, and international law which, by Council, can be applied by looking at disputed matters. After considering various things. In November 1984, the Arbitration Council decided to grant Amco a claim of US $\$ 3,200,000$ plus interest of 6\% per year from January 15th, 1981 until the effective payment date.

On March 18th, 1985, the Government of Indonesia applied for the annulment of that arbitral award, whereby the Ad Hoc Committee canceled a portion of the award. However, the Council maintains that the actions of the Indonesian military and police officers are in violation of the law and Amco is entitled to compensation from the damages it suffers. Finally, in the final award of the ICSID Arbitration Board on August 6th, 1990, that obligated the Indonesian Government to pay compensation of US $\$ 2,677,126.20$ plus $6 \%$ interest from the date of the award until the effective payment date.

\section{The government of Republic of Indonesia v. newmont}

Divestment of shares disputes between Government of Indonesia and Newmont Indonesia Ltd. which conduct a gold mining in Sumbawa, West Nusa Tenggara. According to the gold mining contract, Newmont must divest or transfer some of its shares to the Government of Indonesia, in this case the Central Government, the West Nusa Tenggara Provincial Government and the District Government of Sumbawa. It appears that Newmont is reluctant to implement the divestment program and also has been mortgaged its shares as collateral for the company's loans to overseas banks. Negotiations between the Government and Newmont until today have not reached an agreement, so the Government brings the dispute to the UNCITRAL international arbitration.

\section{THE INSTITUTION OF DISPUTE RESOLUTION IS ONE OF THE INVESTOR CONSIDERATIONS IN CAPITAL INVEST- MENT}

One thing that is often become a consideration of potential investors, if he wants to invest his capital abroad is the existence of dispute resolution institutions between investors and the host state. Conventionally every country in the world is providing dispute resolution institution through litigation, which in theory of constitutional law known as the judiciary. However, if a dispute resolution between investor and host state is settled through the judiciary there is always a doubt among potential foreign investors.

In other words, the level of objectivity of the dispute resolution through litigation is in doubt. Theoretically indeed the existence of the judiciary is independent. This means that this institution cannot be influenced by other institutions (executive and legislative). But psychologically, in the settlement of the dispute between foreign investor and the host state, the court's subjective factor or justice would be difficult to avoid since they are a citizen of the host state (Indonesia Investment, 2017) Therefore it is natural that foreign investors want to know in advance whether it is possible to settle disputes outside the court (alternative).

Regarding the choice of dispute resolution, it is interesting to listen to Longdong (1998): "A major consideration for investors to invest is that adequate legal guarantees provide a means of dispute resolution through foreign arbitration against losses that may arise as a result of investment. Investors and foreign traders are always trying to escape the judiciary of developing countries because they feel they do not know the laws of their own country. In addition, there is a doubt that the local judiciary will be objective. Another reason is whether the state judiciary can ex- 
amine international trade disputes and such complex technology transfer." The same thing also stated by Goodpaster (1995) there are various reasons to choose arbitration institution as dispute resolution that is: "In the world of international trade the visible trend is the liberalization of arbitration rules/law to further encourage the use of arbitration rather than dispute settlement through the litigation process. In general, this law is designed to provide maximum autonomy of freedom and flexibility in resolving disputes. This is done by authorizing the parties to appoint law or fair principles applicable to disputes between them and also authorize them to elect arbitrators as well as procedural rules applicable to arbitration. This means that the parties do not need to apply local law to the dispute they are facing."

Based on the description above, it appears that there is a tendency of investors to choose disputes resolution outside the court. In Indonesia to solve the problem of investment has been firmly described in Investment Law. If carefully considered in the 2007 Investment Law, it appears that the Government of the Republic of Indonesia provides space for resolving investment disputes between investors and the Government of the Republic of Indonesia through arbitration institutions. This is described in Article 32 of the Investment Law.

However, the UUPM does not mentioned which and where arbitral institutions to solve this matter. As it is known, in the level of international law there are a number of international agreements concerning investment issues. As proposed by Abidin (2017); "In terms of international law, there are already several international treaties (both multilateral and bilateral) that govern and protect investments and risks. Investment risks (including political risks) commonly encountered include state or government takeovers of foreign assets and properties and Intellectual Property Rights (known as nationalization), forced re-negotiations of coerced renegotiation contracts, restrictions on repatriation of income and civic activity that undermines the course or operation of foreign investment and others. Violations of international treaties or tractate as well as violations of an investment contracted by a government or a state State due to a legal action or claim to an international arbitration body or to an international court such as the international court of justice".

To strengthen the existence of arbitration institutions as an alternative to dispute resolution especially in investment, the Indonesian government has ratified "the convention on the settlement of investment disputes between states of the nationals of other states" with Law No. 5 year 1968. The convention is also known as the Washington Convention.
This Convention was enacted at the initiative of the World Bank in 1965. This Convention was created to stimulate the entry of foreign capital in developing countries (Ilmar, 2004) as a follow-up to this Convention, a dispute resolution institution has been made between capital investor with host country better known as the ICSID. Hereinafter referred to in this convention as "centre". While the purpose of the establishment of ICSID is to provide facilities for the conciliation and arbitration of State disputes from the other States participating in the provisions of the Convention. For the ICSID to take effect, the parties must agree to submit their dispute to the ICSID arbitration council, the dispute shall be between the participants of the convention or the agent/organizations of that State and citizens of the other Convention's countries, and the dispute concerning the investment (Sornarajah, 2017). In this convention regulated a dispute resolution between investor with host state through arbitration.

The jurisdiction of the ICSID arbitration council is determined by three main elements: First, the dispute must be an arising dispute directly from the investment; Second, both parties to the dispute must be a citizen of a country that has been a member of ICSID; Third, there should be a written statement of agreement from both parties in dispute over the submission of dispute resolution to ICSID. In other words, disputes that can be brought to the ICSID arbitration board are only legal disputes on investment (Sornarajah, 2017).

Other conventions relating to arbitration bodies that have also been ratified by the Indonesian government are "the convention on recognition and implementation of foreign arbitral awards". From the name of the convention is clear "Recognition of foreign arbitration awards" means the parties to the dispute in which one of the parties is a businessman originating from Indonesia, they agree to resolve the dispute through a foreign arbitration institution. The legal consequence is that the parties must acknowledge and voluntarily undertake the award. This Convention is also known to volunteer to carry out the award. This Convention is also known as the 1958 New York Convention (United Nations, 2017). This Convention has been ratified by the Government of Indonesia in accordance with Presidential Decree No. 34/1981. In article III of the New York Convention 1958 states, each State party to this Convention shall recognize its foreign arbitration awards and deem it as binding and enforcing the arbitral award in accordance with the provisions the procedural law applicable in the territory in which the awards was requested to take place (Gautama \& Surjaman, 1989). Theoretically, with the ratification of the 
1958 New York convention by the Indonesian government, the convention became national law. This means that the foreign arbitral award will automatically be recognized and enforceable in Indonesia. However, in reality, the implementation of the foreign arbitral award has not been fully operational as expected. This can be seen from the view of the judiciary in Indonesia in dealing with arbitration in this country is not consistent. The reason used to refute the execution of foreign arbitral rulings is contrary to the public interest (Gautama \& Surjaman, 1989).

It seems that the government is aware that the development of the business world is growing so rapidly that business dispute resolution is demanded quickly. Therefore, a dispute resolution institution outside the judiciary can be used as an alternative to resolve disputes faced by business people. In many countries, the choice of business dispute resolution outside the judiciary has long been recognized, among others, through arbitration institutions. Therefore, in order to strengthen the existence of the arbitration institution (Subekti, 1979) as one of the ARD in Indonesia with the enactment of Law No. 30 Year 1999 concerning Arbitration and Alternative Dispute Resolution (Arbitration Law). With the issuance of this law, the doubts about the implementation of the arbitral award (Article 1 subsection 8, 1999), in particular the international arbitral award (Article 1 subsection 9, 1999) can be minimized a bit. This means that if there is a foreign arbitral award that implemented in Indonesia, as long as it is eligible it can be applied in Indonesia. Therefore, the requirements that must be fulfilled, if you want to implement the foreign arbitration awards in Indonesia are spelled out in Article 66 of Law Number 30 Year 1999 concerning Arbitration and Alternative Dispute Settlement.

"International Arbitration Awards will only be recognized and may only be enforced within the jurisdiction of the Republic of Indonesia if they fulfill the following requirements (1) The International Arbitration Award must have been rendered by an arbitrator or arbitration tribunal in a country which, together with the Republic of Indonesia, is a party to a bilateral or multilateral treaty on the recognition and enforcement of International Arbitration Awards; (2) International Arbitration Awards, as contemplated in item (a), above, are limited to awards which, under the provisions of Indonesian law, fall within the scope of commercial law; (3) International Arbitration Awards, as contemplated in item (a), above, may only be enforced in Indonesia if they do not violate public order; (4) An International Arbitration Award may be enforced in Indonesia only after obtaining an order of Exequatur from the Chief Judge of the District Court of Central Jakarta; and (5) An International Arbitration Award, as contemplated in item (a), in which the Republic of Indonesia is one of the parties to the dispute, may only be enforced after obtaining an order of Exequatur from the Supreme Court of the Republic of Indonesia, which order is then delegated to the District Court of Central Jakarta for execution.

\section{CONCLUSION}

Consideration of potential investors, if he wants to invest his capital abroad is the existence of dispute resolution between investors and host countries. Theoretically indeed the existence of judicial institutions is independent. This means that this institution cannot be influenced by other institutions (executive and legislative). However, psychologically in the dispute's resolution between foreign investors and host countries, the subjective factor of the judiciary or judge would be difficult to avoid since he is a citizen of the host country, therefore it is natural that the investor foreigners would like to know in advance whether it is possible to solve disputes outside the court.

In Indonesia the investment dispute resolution, that the Government of the Republic of Indonesia provides space for resolving investment disputes between investors and the Government of the Republic of Indonesia through arbitration institutions. Indonesia has ratified the New York Convention 1958, then the convention becomes national law. This means that the foreign arbitral award will automatically be recognized and enforceable in Indonesia. Arbitration institutions as one of the ADR in Indonesia became stronger with the enactment of Arbitration Law. With the issuance of this law, the doubts on the execution of arbitral awards, especially international arbitration awards can be minimized. This means that if there is a foreign arbitral award that implemented in Indonesia, as long as it is eligible it can be applied in Indonesia.

Therefore, the arrangements of foreign investment in Indonesia should be also harmonize with the regulation of International Law, in this case the International Trade Law of GATT/WTO and ICSID Convention concerning the settlement of investment disputes between States and Nationals of other States. This does not mean that Indonesia has transferred its sovereignty to the International Law, since the GATT/WTO principles have exceptions and the implementation of the ICSID Convention in dispute settlement must have prior written approval from the Government of Indonesia. 


\section{REFERENCES}

Abidin, R. F. (2017). Harmonisasi peraturan penanaman modal asing dalambidang pertambangan mineral dan batubara berdasarkan prinsip keadilan (Studi kontrak karya antara pemerintah republik Indonesia dengan pt. freeport Indonesia). Az Zarqa, 9(2), 315-364.

Ahmad, N., \& Mazlan, N. F. (2015). Banking fragility sector index and determinants: A comparison between local-based and foreign-based Commercial Banks in Malaysia. International Journal of Business and Administrative Studies, 1(1), 5-17. doi:https://doi.org/10.20469/ijbas.10002

Azeem, Z. (2014). Elements of international trade law. Retrieved from https://goo.gl/jeRZtx (accessed on 14 October, 2017)

Bryant, C. E., \& Javalgi, R. G. (2016). Global economic integration in developing countries: The role of corruption and human capital investment. Journal of Business Ethics, 136(3), 437--450. doi:https://doi.org/10.1007/s10551-014-2490-3

Elgamodi, K. H. A. (2017). The motivational factors for Foreign Direct Investment (FDI) in tourism in Libya (Unpublished master's thesis). University of Salford, Salford, UK.

Gautama, S., \& Surjaman, T. (1989). Perkembangan arbitrase dagang internasional di Indonesia. Jakarta, Indonesia: PT. Eresco, Bandung.

Goodpaster, L. (1995). Tinjauan terhadap arbitrase dagang secara umum dan arbitrase dagang di Indonesia. Jakarta, Indonesia: Yudhistira Ghalia Indonesia.

Hiransomboon, K. (2017). Using convenience store service of foreign backpacker tourists in Bangkok, Thailand. International Jorunal of Business and Economic Affairs, 2(1), 1-7. doi:https://doi.org/10.24088/ijbea-2017-21001

Ilmar, A. (2004). Investment law in Indonesia. Jakarta, Indonesia: Prenada Media.

Indonesia Investment. (2017). Risks of investing in Indonesia. Retrieved from https://goo.gl/8m1ZmH (accessed on July 14, 2017)

Longdong, T. L. (1998). Asas ketertiban umum dan konvensi New York 1958. Bandung, Indonesia: PT. Citra Aditya Bakti.

Mallor, J. P., Barnes, A. J., Bowers, T., \& Langvardt, A. W. (2004). Business law: The ethical, global, and e-commerce environment. Huntersville, NC: McGraw Hill Irwin.

Pradhan, R. P., Arvin, M. B., Nair, M., \& Bennett, S. E. (2017). Venture capital investment, financial development, and economic growth: The case of European single market countries. Venture Capital, 19(4), 313-333.

Raksorn, W. (2016). The role of Russia, China, Iran and their foreign policies towards Syria on the Arab Spring. Journal of Advances in Humanities and Social Sciences, 2(4), 204-220. doi:https://doi.org/10.20474/jahss-2.4.2

Sornarajah, M. (2017). The international law on foreign investment. Cambridge, MA: Cambridge University Press.

Subekti, R. (1979). Trade arbitration. Bandung, Indonesia: Binacipta.

United Nations. (2017). The 1958 new york convention: 60 and still modern. Retrieved from https://goo.gl/CfT4Lf (accessed on 14 October, 2107) 